\title{
АДМІНІСТРАТИВНО-ПРАВОВІ ЗАСОБИ ЗАХИСТУ ОСОБИСТИХ НЕМАЙНОВИХ ПРАВ
}

\author{
ІВАНОВ Володимир Володимирович - студент 2 курсу Магістратури, \\ Навчально-науковий юридичний інституту, спеціальність право, кафедра \\ публічно-правових дисциплін Київського міжнародного університету (КиМУ)
}

DOI:10.32782/LAW.2020.1.10

У статті аналізуються теоретичні положення та нормативні засади адміністративно-правових засобів захисту особистих немайнових прав, визначається їх сутність i значення як елементів механізму, запропоновано способи удосконалення нормативноправового регулювання.

Ключові слова: адміністративно-правовий механізм, спосіб, засіб, захист, особисті немайнові права.

\section{Постановка проблеми}

В умовах постійного реформування правової системи Україні особливої актуальності набуває проблема забезпечення і захисту прав та свобод громадян. Сьогодні однією з ключових проблем організації та реалізації системи захисту особистих немайнових прав $\varepsilon$ недостатня теоретична та законодавча розробленість такої категорії? як «засоби захисту» та його ототожнення 3 поняттям «способи захисту», що призводить до їх спотвореного сприйняття та фрагментарного використання. При цьому адміністративно-правові засоби поруч із цивільно-правовими, конституційними та кримінально-правовими 6 вагомим елементом загальної системи захисту особистих немайнових права громадян. Зазначені обставини і зумовлюють актуальність досліджуваної теми.

\section{Стан дослідження}

Вивченню деяких питань засобів захисту прав громадян присвячено праці та- ких ечених? як: В. Б. Авер'янов, А. В. Амагиров, М. М. Антонович, О. В. Аушева, I. А. Бородін $\lambda$. Н. Буркова, Н. Д. Гетьманцева, Ю. В. Гридасов, Ю. Т. Добромислов, Г. В. Ерьоменко, Т. В. Збирак, І. Г. Козуб, Т. О. Коломоєць, О. А. Кузнєцов, І. В. Лагутіна, Я. В. Аазур, М. В. Лошицький, О. Ф. Мельничук, О. Муза, Ю. Навроцька, Т. А. Плугатар, П. М. Рабінович, І. Ромащенко, О. О. Пунда, О. А. Соколенко, Н. В. Троцюк М. І. Хавронюк, Т. М. Ярова та інші. Не зважаючи на те, що наукові праці цих дослідників можуть стати основою для вирішення певних теоретичних проблем та прийняття нормативно-правових актів у сфері адміністративно-правового захисту прав в Україні, проте у них розкрито механізм захисту прав громадян лише в загальних рисах або ж в аспекті інших систем захисту прав громадян, а низка питань, що стосуються безпосередньо адміністративно-правових засобів захисту особистих немайнових прав (наприклад, поняття адміністративно-правового захисту особистих немайнових прав), є недостатньо розробленими та потребують подальшого дослідження.

\section{Формування мети}

Мета статті полягає у дослідженні та визначенні поняття та ознак адміністративноправових засобів захисту особистих немайнових прав громадян, окресленні напрямів оптимізації та обгрунтуванні рекомендацій щодо їх подальшого удосконалення. 


\section{Виклад основного матеріалу}

Важливим принципом правової держави є забезпеченість і захищеність прав та свобод її громадян. У цьому зв'язку правові засоби захисту прав та свобод громадян посідають вагоме місце у правовому полі держави, оскільки виступають складовою частиною правової системи, яка відповідним чином визначає «зміст і спрямованість діяльності держави» $[1$, с.85]. Тобто завдяки засобам захисту права та свободи громадян стають реальними.

На правовий захист особистих немайнових прав громадян прямо чи опосередковано спрямовані норми багатьох галузей як приватного (цивільного), так і публічного (адміністративного) права. I хоча їх метою $\epsilon$ забезпечення безперешкодного здійснення суб'єктивних прав, шляхи досягнення цієї мети дуже різні.

Так, будучи пов'язане з правами та законними інтересами окремих суб'єктів, цивільне право спрямоване, коли це можливо, на відновлення становища, що існувало до порушення, а в іншому випадку, - на відшкодування шкоди, заподіяної протиправним посяганням на нематеріальні блага. Адміністративне право служить одним 3 основних критеріїв ефективності діяльності держави, оскільки пов'язане не стільки 3 правами та інтересами окремих індивідів, скільки всіх суб'єктів права і спрямоване на відновлення соціальної справедливості та задоволення особистих немайнових інтересів потерпілих або інших осіб. При цьому адміністративно-правовий захист характеризується відмінністю засобів захисту.

Досліджуючи засоби адміністративноправового захисту особистих немайнових прав, вважаємо логічним спершу зупинитися на тлумаченні понять «способи» та «засоби», оскільки нормативно-правове регулювання не визначає ані сутності досліджуваних понять, ані відповідно їхнього співвідношення, внаслідок чого точаться численні дискусії з приводу їх трактування.

Загалом юриспруденція запозичила поняття «засіб» у філософії, в якій розуміють його як сукупність предметів, ідей, явищ та способів дій, які є неодмінною умовою реалізації цілі $[2,206]$. При цьому поняття «за- сіб» та «спосіб» співвідносяться відповідно як ціле та частина.

Більшість сучасних словників української мови, даючи наступне трактування досліджуваних понять: спосіб - це певна дія, прийом або система прийомів, яка дає можливість зробити, здійснити що-небудь, досягти чогось [3, с.578]; засіб - це прийом, якась спеціальна дія, що дає можливість здійснити що-небудь, досягти чогось; спосіб; те, що служить знаряддям у якій-небудь дії, справі [4, с.307], - по суті, ототожнює їх.Висловлюється думка, що антонімом до слова «засіб» $е$ слово «мета» («ціль»), а синонімами - «спосіб», «метод», «прийом», «знаряддя», «інструмент», «механізм», «прилад» тощо [5].

У науковій спільноті відсутня єдність позицій щодо сутності, змісту і співвідношення понять «спосіб» і «засіб захисту». Так, окремі дослідники взагалі не розділяють способи та засоби захисту і вживають їх як тотожні поняття [6]. Інші підтримують концепцію, за якою категорії «спосіб» та «засіб захисту» $є$ схожими і пропонують вважати під способами правового захисту «засоби правового впливу, які застосовуються компетентними органами щодо зобов'язаних осіб або правопорушників із метою відновлення порушеного (оспореного) права людини» [7, с.295]. Існує також i третій підхід до тлумачення досліджуваних понять, за яким терміни «правові засоби» i «способи» близькі за змістом, але їх не слід ототожнювати хоча 6 тому, що способи чітко встановлюються законом або договором, а правові засоби належать не лише до матеріального світу, але й до інтелектуальної сфери [8].

На практиці тісний взаємозв'язок і взаємозалежність, що існує між категоріями «способи» та «засоби», часто призводить до змішування понять, хоча у суворому розумінні вони означають різні дії, спрямовані на захист прав, тобто різні елементи (види або частини) діяльності із захисту суб'єктивних прав [9, с.41]. Приміром, Н. Д. Гетьманцева вважає, що спосіб захисту - сукупність дій, за допомогою яких відновлюються, визнаються, встановлюються права та законні інтереси особи. Засіб 
захисту - це сукупність дій, спрямованих на відновлення, визнання і встановлення прав та законних інтересів особи. Спосіб захисту є засобом для форми захисту. При цьому кожний спосіб захисту має свої засоби [10]. Таким чином, слід розрізняти поняття «спосіб захисту прав» та «засіб захисту прав», які, попри тісний взаємозв'язок, не є тотожними.

Говорячи про способи захисту, іноді вживають також термін «міра захисту», який є синонімом слова «способи», і термін «метод захисту», що є не зовсім точним, оскільки «метод»- це сукупність певних засобів і способів. Використання терміна «вид захисту» не є помилкою, однак він означає поняття більш загального порядку [11].

Щодо поняття «адміністративно-правових засобів захисту прав громадян» у сучасних наукових дослідженнях також немає єдиного підходу до його розуміння, внаслідок чого відсутне й чітке та грунтовне формулювання його сутності.

На думку О. А. Соколенко, «поняття адміністративно-правових засобів захисту прав громадян за своєю суттю є досить широким, а тому в умовах демократичної соціально-правової держави не може і не має бути остаточно визначеним» [12, с.97]. Ми не можемо погодитись 3 такою позицією, оскільки вважаємо, що тільки завдяки чіткому визначенню поняття можна зрозуміти його сутність і значення.

Т. В. Збирак пропонує під адміністративно-правовими способами захисту права громадян розуміти «врегульовану адміністративно-правовими нормами діяльність уповноважених органів та їх посадових осіб, спрямовану на правильне розуміння та застосування чинного законодавства, що визначає право громадян...». Адміністративно-правові засоби захисту дослідник визначає як «сукупність різних за своєю сутністю та призначенням правових явищ, інструментів, заходів, які спільно вирішують завдання запобігання та припинення порушень ... права, а також його відновлення у разі порушення» [13].

H. В. Троцюк під «адміністративноправовими засобами» визначає сукупність прийомів і методів діяльності державних органів, що спрямована на врегулювання суспільних відносин із метою ефективної реалізації права на захист [14]. Проте ми не можемо погодитись із таким визначенням поняття, оскільки загальновідомо ще з теорії права, що метод є сукупністю засобів, а не навпаки.

В. О. Іванцов під «адміністративноправовими засобами» визнає сукупність установлених нормами адміністративного права прийомів і способів, за допомогою яких держава в особі уповноважених державних органів виконавчої влади впливає на суспільні відносини в зазначеній сфері шляхом застосування до фізичних та юридичних осіб, які не перебувають у їх підпорядкуванні, незалежно від волі і бажання останніх, примусових заходів впливу морального, майнового, організаційного та особистісного характеру у випадках вчинення або загрози вчинення особами правопорушення, об'єктом яких є суспільні відносини в досліджуваній сфері, з метою попередження та припинення порушень загальнообов'язкових правил, притягнення винних до відповідальності [15].

А.М. Комзюк під «адміністративно-правовими засобами», розуміє всю систему адміністративно-правових норм, яка розглядається з позиції їхнього функціонального призначення для вирішення певного кола соціальних завдань, регулювання відповідних суспільних відносин [16, с.44-48].

Досліджуючи категорію «адміністративно-правові засоби» А. М. Комзюк концентрує увагу на їх багатоманітності та зазначає, що вони є взаємопов'язаними і взаємозалежними та становлять цілісну систему, перетинаються 3 кримінально-правовими, фінансово-правовими, економічними заходами, різноманітними методами організаційно-масової діяльності. Тільки раціональне використання різноманітних засобів у взаємозв'язку, обгрунтований вибір основних із них, уміле їх поєднання і створюють умови для належного забезпечення досягнення бажаних результатів. Вибір конкретного адміністративно-правового засобу, доцільність його застосування в тій чи іншій ситуації визначаються умовами, що склалися, наявністю певних обставин, 


\section{Адміністративне право}

завданнями й компетенцією органу (посадової особи), який діє в даній ситуації [16, c. 46$]$.

О. Я. Савчук пропонує наступне визначення детермінанти «адміністративно-правові засоби»: це діяльність органів публічної адміністрації, що здійснюеться за допомогою адміністративно-правових норм через прийоми та способи, метою якої є забезпечення та захист прав осіб від протиправних діянь із притягненням правопорушників до відповідальності [17, с.95].

Будучи відображенням практичної сторони юридичних процедур, засоби адміністративно-правового захисту забезпечують реальне вирішення проблемних питань та сприяють забезпеченню виконання потреб, пов'язаних із реалізацією фізичними особами особистих немайнових прав.

Адміністративно-правовий засіб має специфічні ознаки, з'ясування яких обумовлює необхідність аналізу найбільш специфічних його властивостей: призначення; органів, що здійснюють захист особистих немайнових прав; характерних рис, змісту та порядку здійснення діяльності. Так, основними ознаками адміністративно-правового засобу захисту особистих немайнових прав є: по-перше, їх призначення перебуває в прямій залежності від мети й завдань державного управління, визначається характером і змістом останнього; по-друге, для здійснення адміністративноправового захисту особистих немайнових прав держава формує або створює умови для формування спеціального апарату; потретє, мають специфічні особливості, що визначають його місце й роль у системі інших засобів захисту, зокрема, вони полягають у тому, що захист права власності адміністративно-правовим засобом ведеться не безупинно, а лише у разі його порушення; по-четверте, адміністративно-правові засоби використовуються і при реалізації фізичними особами права на самооборону (необхідну оборону, крайньої необхідності та затримання особи, що вчинила злочин) [18]; по-четверте, існують у формі субстанційних та діяльнісних правових інструментів виховного, роз'яснювального, заохочувального, морального, майнового, фізичного та іншого характеру та спрямовані на формування у громадян розуміння непорушності прав і законних інтересів у сфері власності, попередження правопорушень, покарання та виховання правопорушників, відшкодування заподіяної шкоди; по-п'яте, підтримуються державою та застосовуються органами публічної влади, громадськими формуваннями, громадянами; по-шосте, реалізуються у межах наявних способів адміністративно-правового захисту особистих немайнових прав фізичних осіб; по-сьоме, мають своїми завданнями відновлення порушеного законного інтересу, застосування державного примусу до осіб, які своїми протиправними діями завдали шкоди законним інтересам громадян у сфері реалізації особистих немайнових прав, реалізацію контрольних повноважень за правомірністю дій посадових осіб органів влади у зазначеній сфері; по-восьме, наслідком їх застосування є усунення адміністративних правопорушень, ліквідація результатів неправомірних рішень, дій чи бездіяльності суб'єктів владних повноважень, відновлення правового становища особи, яке існувало до порушення іiі особистих немайнових прав.

Здійснивши аналіз різних поглядів на визначення поняття «адміністративноправовий засіб захисту» та їх дослідження крізь призму захисту особистих немайнових прав, а також визначивши ознаки адміністративно-правового засобу захисту особистих немайнових прав, ми пропонуємо під «засобами адміністративно-правового захисту особистих немайнових прав» розуміти сукупність передбачених законом організаційних, майнових та немайнових, фактичних та юридичних, профілактичних (превентивних), відновлювальних та штрафних інструментів і форм державної захисної діяльності органів влади та органів місцевого самоврядування, а також захисної діяльності громадян у сфері адміністративно-правового регулювання та забезпечення реалізації особистих немайнових прав, протидії правопорушенням, відновленням правових можливостей осіб у цій сфері, відшкодування заподіяної шкоди. Вбачаємо за потрібне закріпити це ви- 
значення на законодавчому рівні для розмежування адміністративно-правових засобів захисту особистих немайнових прав від інших галузевих засобів.

Висновки. Таким чином, адміністративно-правові засоби захисту особистих немайнових прав $є$ своєрідним містком між академічною теорією адміністративно-правового захисту особистих немайнових прав і практичними рекомендаціями правозастосовної та правоохоронної діяльності органів виконавчої влади та місцевого самоврядування у цій сфері.

\section{Мiтература}

1. Бородін I. $\lambda$. Адміністративно-правові способи захисту прав та свобод людини і громадянина: монографія. Херсон: Вид-во «Олді-плюс», 2003. 218 с.

2. Філософський словник / за ред. В. I. Шинкарука: 2-ге вид., перероб і доп. Київ: Голов. ред. УРЕ, 1986. 800 с.

3. Словник української мови: в 11 томах. Том 9, 1978. http://sum.in.ua/p/9/578/2 (дата звернення: 07.10.2019)

4. Словник української мови: в 11 томах. Том 3, 1972. http://sum.in.ua/p/3/307/2 (дата звернення: 07.10.2019)

5. Словник синонімів Караванського. Словопедія. URL: http://slovopedia.org. ua/41/53399/265238.html (дата звернення: $08.10 .2019)$

6. Тимошенко $\curlywedge$. В. Основні форми захисту особистих майнових та немайнових прав в Україні та їх практичне застосування. URL: file://C:/Users/Admin/ Downloads/6855-13766-1-SM.pdf. (дата звернення: 09.10.2019)

7. Стремоухов А. Правовая защита человека. Москва: Норма, 2006. 352 с.

8. Мельничук О. Правові засоби та способи захисту суб'єктивного права на освіту. Адвокат. 2011. № 4. С. 23-27. URL: http:// nbuv.gov.ua/UJRN/adv_2011_4_4. (дата звернення: 09.10.2019)

9. Чечот Д. Субъективное гражданское право и формы его защиты. Аенинград: Изд-во АГУ, 1968. 71 с.

10. Гетьманцева Н., Козуб І. Засіб, спосіб і форма захисту трудових прав. Адвокат.
2009. № 11. C. 37-42. URL: http://nbuv.gov. ua/UJRN/adv_2009_11_7.

11. Притика Ю. Поняття і диференціація способів захисту цивільних прав та інтересів. Вісник Київсъкого національного університету імені Тараса Шевченка. Юридичні науки. 2004. Випуск № 60/62. URL: http://papers. univ.kiev.ua/1/jurydychni_nauky/articles/ prytyka-y-the-definition-and-differentiationof-the-methods-of-the-defense-of-ci_17933. pdf (дата звернення: 09.10.2019)

12. Соколенко Л.О. Поняття, значення та система адміністративно-правових засобів захисту прав громадян. Право $i$ безпека. 2012. № 5(47). С. 95-100.

13. Збирак Т. В. Сутність і значення адміністративно-правових засобів та способів захисту права громадян на свободу слова. Форум права. 2013. № 3. С. 239-244. URL: $\quad$ http://nbuv.gov.ua/j-pdf/FP index. htm_2013_3_41.pdf (дата звернення: $09 . \overline{10} .201 \overline{9})$

14. Троцюк Н.В. Щодо поняття адміністративно-правових засобів захисту авторських прав. URL : http://law.nau.edu.ua/ images/Nauka/Repozitarij/KCPP_Kafedra_ civilnogo_prava_i_procesu. (дата звернення: $09.10 .2019)$

15. Іванцов В.О. Поняття та особливості адміністративно-правових засобів протидії правопорушенням у галузі фінансів. Вісник Харківсъкого начіонального університету внутрішніх справ. 2008. № 42.C. 207-213.

16. Комзюк А.Т. Заходи адміністративного примусу в правоохоронній діяльності міліції: поняття, види та організаційноправові питання реалізації: монографія / За заг. ред. О.М. Бандурки. Харків: Вид-во Нац. ун-ту внутр. справ, 2002. 345 с.

17. Савчук О. Я. Класифікація засобів адміністративно-правового захисту дітейсиріт та дітей, позбавлених батьківського піклування. Науковий вісник публічного та приватного права. 2019. Випуск 1, том 2. C. $92-96$

18. Галунько В.В. Адміністративноправова охорона права власності в Україні: дис. ... докт. юрид. наук. Харків, 2009. 483 c. 


\section{Адміністративне право \\ ADMINISTRATIVE AND LEGAL MEANS OF PROTECTION OF PERSONAL NON-PROPERTY RIGHT}

The article analyzes the theoretical provisions and normative principles of administrative and legal means of protection of personal non-property rights, defines their essence and significance as elements of the mechanism, suggesting the ways to improve normative legal regulation.

The norms of many fields of jurisprudence - both private (civil) and public (administrative) are directly or indirectly aimed to protect personal non-property rights of citizens by law.

While examining the means of administrative legal protection of personal non-property rights, we consider it logical for the start to pay attention to the interpretation of the concepts of "methods" and "means", as soon as normative legal regulation do not define the essence of the studied concepts or their relationship. As a consequence that leads to a numerous discussions about their interpretation.

Moreover, in modern scientific studies there is no single approach to the understanding of the concept of "administrative and legal means of protection of citizens' rights" and as a result of that there is no clear and thorough formulation of its essence.

Administrative-legal means has specific features, the clarification of which necessitates the analysis of its most specific properties: purpose; bodies that protect personal nonproperty rights; characteristics, contents and procedure describing the order of action.
On the basis of different points of view concerning the definition of "administrative and legal means" that were analyzed and taking into consideration their research through the prism of protection of personal non-property rights, as well as identifying the features of administrative and legal protection of personal non-property rights, we offer under "administrative and legal protection of personal nonproperty rights" understand the set of statutory organizational, property and non-property, factual and legal, preventive (prophylactic), restorative and punitive instruments and forms of state protective practices by public authorities and local municipal bodies, as well as protective activities of citizens in the field of administrative and legal regulation and ensuring the implementation of personal non-property rights, combating offenses, restoring the legal capacity of citizens in this area, ensuring compensation for damage. We see the need to consolidate this definition at the legislative level to distinguish administrative and legal means of protection of personal non-property rights from means in other fields of law.

Thus, administrative and legal means of protection of personal non-property rights are a kind of bridge between the academic theory of administrative and legal protection of personal non-property rights and practical recommendations for law enforcement actions of state executive authorities and local municipal bodies in this area.

Key words: administrative-legal mechanism, method, means, protection, personal non-property rights. 